\title{
Hosoya Polynomial and Wiener Index of Zero-Divisor Graph of $Z_{n}$
}

Husam Q. Mohammad

husam_alsabawi@yahoo.com

College of Computer Sciences and Mathematics

University of Mosul, Mosul, Iraq

Received on: 23/02/2014

Accepted on: 09/04/2014

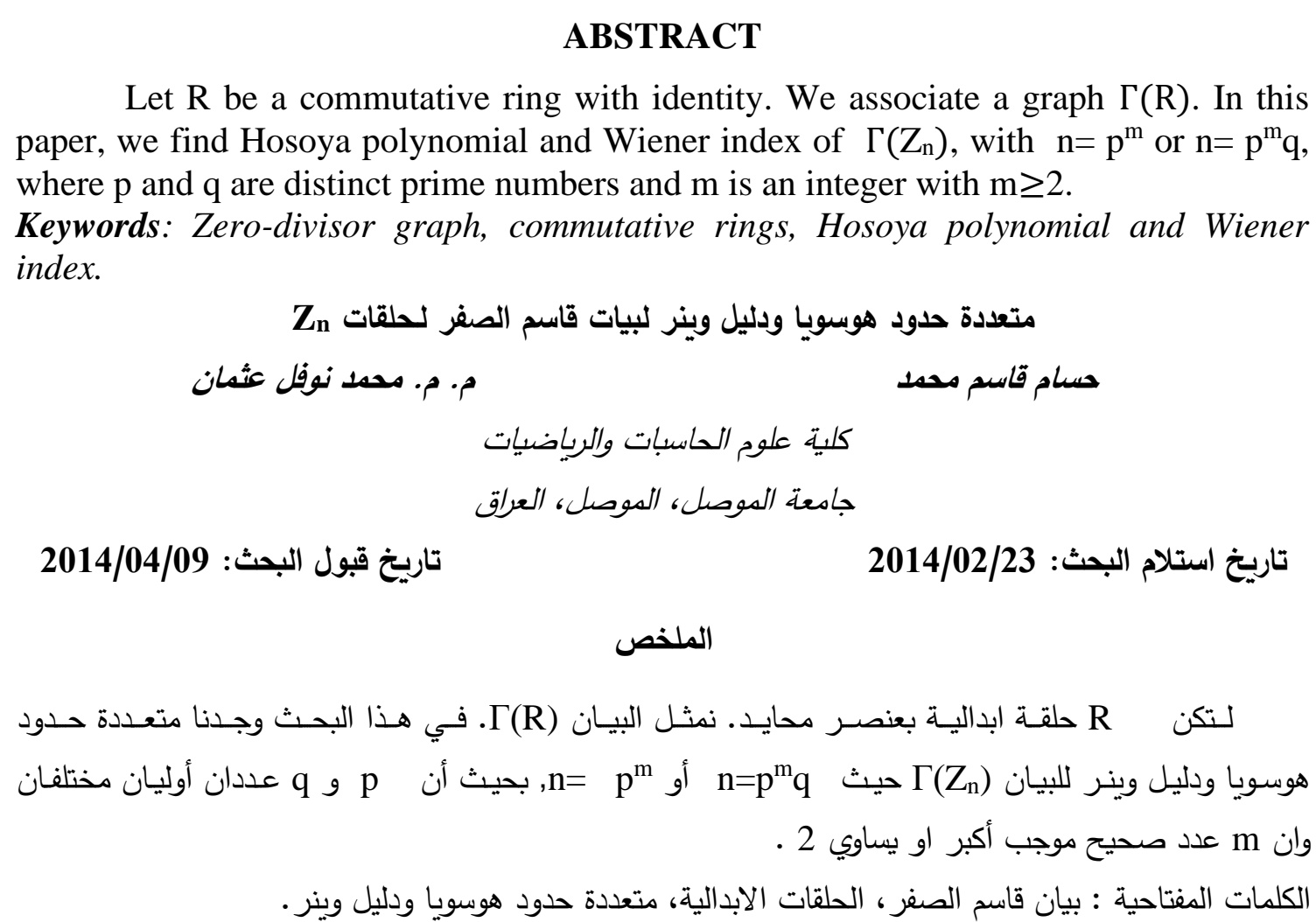

\section{Introduction}

Let $\mathrm{R}$ be a commutative ring with identity, and let $\mathrm{Z}(\mathrm{R})$ be the set of all zerodivisors in $R$, and $Z^{*}(R)$ is the set of all non-zero zero-divisors in it. We associate a simple graph $\Gamma(R)$ to $R$ with vertices $Z^{*}(R)$, and for two distinct vertices $x, y \in Z^{*}(R)$, there is an edge connecting $\mathrm{x}$ and $\mathrm{y}$ if and only if $\mathrm{xy}=0$.

The notion of a zero divisor graph of a commutative ring was first introduced in 1988 by Beck in [5], where he was interesting in colorings. This investigation of coloring of a commutative ring was then continued by Anderson and Naseer in [3], and further Anderson and Livingston in [2] associate a graph $\Gamma(\mathrm{R})$ to $\mathrm{R}$. The principal ideal of an $\mathrm{R}$ is an ideal that is generated by one element of $\mathrm{R}$, say a, and usually denoted by (a). The ring $\mathrm{R}$ is called local ring if it contains exactly one maximal ideal.

A graph $\mathrm{G}$ is said to be connected [6] if there is a path between any two distinct vertices of $G$. For vertices $x$ and $y$ of $G$, let $d(x, y)$ be the length of a shortest path from $x$ to $y$. The diameter of $G$ is defined by $\operatorname{diam}(G)=\max \{d(x, y): x, y \in V(G)\}$, where $V(G)$ is the set of all vertices of $G$. A graph is complete if every two of its vertices are adjacent, so the complete graph of order $n$ is denoted by $K_{n}$. The complement $\bar{K}_{n}$ of the 
complete graph $K_{n}$ has $n$ vertices and no edges, and is referred to as the empty graph of order $\mathrm{n}$. The subsets $\mathrm{V}_{1}, \mathrm{~V}_{2}, \ldots, \mathrm{V}_{\mathrm{r}}, \mathrm{r} \geq 2$, are called $\mathrm{r}$-partite of the set $\mathrm{V}(\mathrm{G})$, if $\mathrm{V}_{\mathrm{i}}$ is non empty, and the intersection between $V_{i}$ and $V_{j}$ is empty for any $1 \leq i, j \leq r$ with $i \neq j$, so that $U_{i=1}^{r} V_{i}=V(G)$.

Hosoya polynomial of the graph $\mathrm{G}$ is defined by : $\mathrm{H}(\mathrm{G} ; \mathrm{x})=\sum_{\mathrm{k}=0}^{\operatorname{diam}(G)} \mathrm{d}(\mathrm{G}, \mathrm{k}) \mathrm{x}^{\mathrm{k}}$, where $d(G, k)$ is the number of pairs of vertices of a graph $G$ that are at distance $k$ apart, for $\mathrm{k}=0,1,2, \ldots, \operatorname{diam}(\mathrm{G})$. The Wiener index of $\mathrm{G}$ is defined as the sum of all distances between vertices of the graph, and denoted by $\mathrm{W}(\mathrm{G})$, and we can find this index by differentiating Hosoya polynomial for the given distance with respect to $\mathrm{x}$ and putting $\mathrm{x}$ $=1$. See $[7,9]$.

As usual we shall assume that $\mathrm{p}$ and $\mathrm{q}$ are distinct positive prime numbers and $\mathrm{m}$ be an integer with $m \geq 2$. In [1] Ahmadi and Nezhad proved some results concerning the Wiener index of $\Gamma\left(Z_{n}\right)$, where $n=p^{2}$, pq and $p^{2} q$. In this paper we extended these results to $n=p^{m}, p^{m} q$.

\section{Hosoya Polynomial and Wiener Index of $\Gamma\left(Z_{p^{m}}\right)$}

In this section, we find the Hosoya polynomial and the Wiener index of $\Gamma\left(Z_{p^{m}}\right)$. It is clear that $\mathrm{Z}^{*}\left(\mathrm{Z}_{\mathrm{p}^{\mathrm{m}}}\right)=(\mathrm{p}) \backslash\{0\}=\left\{\mathrm{p}, 2 \mathrm{p}, 3 \mathrm{p}, \ldots,\left(\mathrm{p}^{\mathrm{m}-1}-1\right) \mathrm{p}\right\}$, so we have $\left|Z^{*}\left(Z_{p^{m}}\right)\right|=p^{m-1}-1$. We shall begin this section with the following lemma :

Lemma 2.1 [8, Lemma 2.1.] : Let $Z_{n}$ be a ring of integers modulo $n$. Then, the number of all non-zero zero-divisors for $\mathrm{k} \mid \mathrm{n}$ are $\frac{\mathrm{n}}{\mathrm{k}}-1$.

Theorem 2.2 : $\Gamma\left(\mathrm{Z}_{\mathrm{p}^{3}}\right) \cong \mathrm{K}_{\mathrm{p}-1}+\overline{\mathrm{K}}_{\mathrm{p}^{2}-\mathrm{p}}$

Proof : Since $\mathrm{p}$ is a prime number, then it is clear that the ring $\mathrm{Z}_{\mathrm{p}^{3}}$ is a local ring, so we have $Z^{*}\left(Z_{p^{3}}\right)=(p) \backslash\{0\}=\left\{k p: k=1,2,3, \ldots, p^{2}-1\right\}$.

Now, we can classify $Z^{*}\left(Z_{p^{3}}\right)$ into the two disjoint subsets as follows :

$A_{1}=\left(p^{2}\right) \backslash\{0\}$, and $A_{2}=(p) \backslash\left\{A_{1} \cup\{0\}\right\}$. It is clear that $Z^{*}\left(Z_{p^{3}}\right)=A_{1} \cup A_{2}$ and by using Lemma 2.1 we have $\left|A_{1}\right|=\frac{p^{3}}{p^{2}}-1=p-1$, and $\left|A_{2}\right|=\frac{p^{3}}{p}-\left(\frac{p^{3}}{p^{2}}-1+1\right)=$ $\mathrm{p}^{2}-\mathrm{p}$, so we can write $\mathrm{A}_{1}=\left\{\mathrm{k}_{1} \mathrm{p}^{2}: \mathrm{k}_{1}=1,2, \ldots, \mathrm{p}-1\right\}$ and $\mathrm{A}_{2}=\left\{\mathrm{k}_{2} \mathrm{p}: \mathrm{k}_{2}=1,2, \ldots, \mathrm{p}^{2}-1 ; \mathrm{p} \nmid\right.$ $\left.\mathrm{k}_{2}\right\}$.

Now, let $x, y \in Z^{*}\left(Z_{p^{3}}\right)$. Then, there are three cases :

Case 1: If $\mathrm{x}, \mathrm{y} \in \mathrm{A}_{1}$, then there exists positive integers $\mathrm{k}_{1}$ and $\mathrm{k}_{2}$ with $\mathrm{p} \nmid \mathrm{k}_{1}, \mathrm{k}_{2}$ such that $\mathrm{x}=\mathrm{k}_{1} \mathrm{p}^{2}$ and $\mathrm{y}=\mathrm{k}_{2} \mathrm{p}^{2}$, and we have $\mathrm{xy}=\mathrm{k}_{1} \mathrm{p}^{2} \mathrm{k}_{2} \mathrm{p}^{2}=\mathrm{k}_{1} \mathrm{k}_{2} \mathrm{p}^{4} \equiv 0\left(\bmod \mathrm{p}^{3}\right)$, then $\mathrm{x}$ adjacent with $\mathrm{y}$ in this case .

Case 2: If $x \in A_{1}$ and $y \in A_{2}$, then there exists positive integers $k_{1}$ and $k_{2}$ with $p \nmid k_{1}, k_{2}$ such that $\mathrm{x}=\mathrm{k}_{1} \mathrm{p}^{2}$, and $\mathrm{y}=\mathrm{k}_{2} \mathrm{p}$, and we have

$\mathrm{xy}=\mathrm{k}_{1} \mathrm{p}^{2} \mathrm{k}_{2} \mathrm{p}=\mathrm{k}_{1} \mathrm{k}_{2} \mathrm{p}^{3} \equiv 0\left(\bmod \mathrm{p}^{3}\right)$, then $\mathrm{x}$ adjacent with $\mathrm{y}$ in this case .

Case 3: If $x, y \in A_{2}$, then there exists positive integers $k_{1}$ and $k_{2}$ with $p \nmid k_{1}, k_{2}$ such that $\mathrm{x}=\mathrm{k}_{1} \mathrm{p}$ and $\mathrm{y}=\mathrm{k}_{2} \mathrm{p}$, and we have $\mathrm{xy}=\mathrm{k}_{1} \mathrm{p} \mathrm{k}_{2} \mathrm{p}=\mathrm{k}_{1} \mathrm{k}_{2} \mathrm{p}^{2} \not \equiv 0\left(\bmod \mathrm{p}^{3}\right)$, then $\mathrm{x}$ and $\mathrm{y}$ are not adjacent in this case.

From the previous, we see that every vertex in $A_{1}$ is adjacent with any other vertex in $A_{1}$ and $A_{2}$, so that no vertex in $A_{2}$ is adjacent with any other vertex in $A_{2}$, therefore we have : $\Gamma\left(\mathrm{Z}_{\mathrm{p}^{3}}\right) \cong \mathrm{K}_{\left|\mathrm{A}_{1}\right|}+\overline{\mathrm{K}}_{\left|\mathrm{A}_{2}\right|}=\mathrm{K}_{\mathrm{p}-1}+\overline{\mathrm{K}}_{\mathrm{p}^{2}-\mathrm{p}}$ 
Theorem 2.3: $\mathrm{H}\left(\Gamma\left(\mathrm{Z}_{\mathrm{p}^{3}}\right) ; \mathrm{x}\right)=\mathrm{a}_{0}+\mathrm{a}_{1} \mathrm{x}+\mathrm{a}_{2} \mathrm{x}^{2}$, where $\mathrm{a}_{0}=\mathrm{p}^{2}-1, \quad \mathrm{a}_{1}=\frac{1}{2}\left(2 \mathrm{p}^{3}-3 \mathrm{p}^{2}-\mathrm{p}\right.$ $+2)$, and $\mathrm{a}_{2}=\frac{1}{2}\left(\mathrm{p}^{4}-2 \mathrm{p}^{3}+\mathrm{p}\right)$.

Proof : From clearly that $\operatorname{diam}\left(\Gamma\left(\mathrm{Z}_{\mathrm{p}^{3}}\right)\right)=\mathrm{d}(\mathrm{x}, \mathrm{y})=2$, for all $\mathrm{x}, \mathrm{y} \in \mathrm{A}_{2}$, therefore $\mathrm{H}\left(\Gamma\left(\mathrm{Z}_{\mathrm{p}^{3}}\right), \mathrm{x}\right)=\mathrm{a}_{0}+\mathrm{a}_{1} \mathrm{x}+\mathrm{a}_{2} \mathrm{x}^{2}$, where $\mathrm{a}_{\mathrm{i}}=\mathrm{d}\left(\Gamma\left(\mathrm{Z}_{\mathrm{p}^{3}}\right)\right.$, i ) for $\mathrm{i}=0,1,2$. It is clear that $\mathrm{a}_{0}=$ $\mathrm{d}\left(\Gamma\left(\mathrm{Z}_{\mathrm{p}^{3}}\right), 0\right)=\left|\mathrm{Z}^{*}\left(Z_{\mathrm{p}^{3}}\right)\right|=\mathrm{p}^{2}-1$.

Now, let $Z^{*}\left(Z_{p^{3}}\right)=A_{1} \cup A_{2}$, where $A_{1}=\left(p^{2}\right) \backslash\{0\}$ and $A_{2}=(p) \backslash\left\{A_{1} \cup\{0\}\right\}$ and by Lemma 2.1 we have, $\left|A_{1}\right|=p-1$, and $\left|A_{2}\right|=p^{2}-p$.

To find $a_{1}$, let $x, y \in Z^{*}\left(Z_{p^{3}}\right)$ such that $d(x, y)=1$, from the proof of Theorem 2.2 we get that $d(x, y)=1$ if and only if $x, y \in A_{1}$ or $x \in A_{1}$ and $y \in A_{2}$, then we have : $\mathrm{p}+2)$

$\mathrm{a}_{1}=\mathrm{d}\left(\Gamma\left(\mathrm{Z}_{\mathrm{p}^{3}}\right), 1\right)=\left(\begin{array}{c}\left|\mathrm{A}_{1}\right| \\ 2\end{array}\right)+\left|\mathrm{A}_{1}\right|\left|\mathrm{A}_{2}\right|=\left(\begin{array}{c}\mathrm{p}-1 \\ 2\end{array}\right)+(\mathrm{p}-1)\left(\mathrm{p}^{2}-\mathrm{p}\right)=\frac{1}{2}\left(2 \mathrm{p}^{3}-3 \mathrm{p}^{2}-\right.$

To find $a_{2}$, let $x, y \in Z^{*}\left(Z_{p^{3}}\right)$ such that $d(x, y)=2$, from the proof of Theorem 2.2, we have $d(x, y)=2$ if and only if $x, y \in A_{2}$, then we have :

$$
\mathrm{a}_{2}=\mathrm{d}\left(\Gamma\left(\mathrm{Z}_{\mathrm{p}^{3}}\right), 2\right)=\left(\begin{array}{c}
\left|\mathrm{A}_{2}\right| \\
2
\end{array}\right)=\left(\begin{array}{c}
\mathrm{p}^{2}-\mathrm{p} \\
2
\end{array}\right)=\frac{1}{2}\left(\mathrm{p}^{4}-2 \mathrm{p}^{3}+\mathrm{p}\right) .
$$

Corollary 2.4 : $\mathrm{W}\left(\Gamma\left(\mathrm{Z}_{\mathrm{p}^{3}}\right)\right)=\frac{1}{2}\left(2 \mathrm{p}^{4}-2 \mathrm{p}^{3}-3 \mathrm{p}^{2}+\mathrm{p}+2\right)$.

Proof : Since $\mathrm{W}\left(\Gamma\left(\mathrm{Z}_{\mathrm{p}^{3}}\right)\right)=\left.\frac{\mathrm{d}}{\mathrm{dx}} \mathrm{H}\left(\Gamma\left(\mathrm{Z}_{\mathrm{p}^{3}}\right) ; \mathrm{x}\right)\right|_{\mathrm{x}=1}$, then we have $\mathrm{W}\left(\Gamma\left(\mathrm{Z}_{\mathrm{p}^{3}}\right)\right)=0+\frac{1}{2}(2$ $\left.\mathrm{p}^{3}-3 \mathrm{p}^{2}-\mathrm{p}+2\right)+\left.2 \mathrm{x}\left(\frac{1}{2}\left(\mathrm{p}^{4}-2 \mathrm{p}^{3}+\mathrm{p}\right)\right)\right|_{\mathrm{x}=1}$

$$
=\frac{1}{2}\left(2 p^{4}-2 p^{3}-3 p^{2}+p+2\right) \text {. }
$$

Next, we give the following definition .

Definition 2.5 : Let $Z_{p^{m}}$ be the ring of integers modulo $p^{m}$. Then we can write $Z^{*}\left(Z_{p^{m}}\right)=$ $U_{i=1}^{m-1} A_{i}$, where $A_{i}$ are disjoint subsets of $Z^{*}\left(Z_{p^{m}}\right)$, for $1 \leq i \leq m-1$, which are defined as follows :

$\mathrm{A}_{1}=\left(\mathrm{p}^{\mathrm{m}-1}\right) \backslash\{0\}, \mathrm{A}_{2}=\left(\mathrm{p}^{\mathrm{m}-2}\right) \backslash\left\{\mathrm{A}_{1} \cup\{0\}\right\}, \mathrm{A}_{3}=\left(\mathrm{p}^{\mathrm{m}-3}\right) \backslash\left\{\mathrm{A}_{1} \cup \mathrm{A}_{2} \cup\{0\}\right\}, \ldots$,

$A_{m-1}=(p) \backslash\left\{\left\{\bigcup_{i=1}^{m-2} A_{i}\right\} \cup\{0\}\right\}$.

Notice that, from Lemma 2.1, we get

$\left|A_{i}\right|=p^{i}-p^{i-1}$, for any $1 \leq \mathrm{i} \leq \mathrm{m}-1$, so that we can write

$A_{i}=\left\{k_{i} p^{m-i}: k_{i}=1,2, \ldots, p^{i}-1 ; p \nmid k_{i}\right\}$, for any $1 \leq \mathrm{i} \leq \mathrm{m}-1$.

Lemma 2.6 : Let $A_{i}$, for $1 \leq i \leq m-1$ be subsets of $Z^{*}\left(Z_{p^{m}}\right)$ which are defined in Definition 2.5 and let $s$ and $t$ are two integers with $1 \leq \mathrm{s} \leq \mathrm{t} \leq \mathrm{m}-1$, then $\sum_{\mathrm{i}=\mathrm{s}}^{\mathrm{t}}\left|\mathrm{A}_{\mathrm{i}}\right|=$ $\mathrm{p}^{\mathrm{t}}-\mathrm{p}^{\mathrm{s}-1}$.

Proof: Since, $\left|A_{i}\right|=p^{i}-p^{i-1}, \forall 1 \leq i \leq m-1$, then we have

$$
\begin{aligned}
\sum_{\mathrm{i}=\mathrm{s}}^{\mathrm{t}}\left|\mathrm{A}_{\mathrm{i}}\right| & =\sum_{\mathrm{i}=\mathrm{s}}^{\mathrm{t}}\left(\mathrm{p}^{\mathrm{i}}-\mathrm{p}^{\mathrm{i}-1}\right)=\mathrm{p}^{\mathrm{s}}-\mathrm{p}^{\mathrm{s}-1}+\mathrm{p}^{\mathrm{s}+1}-\mathrm{p}^{\mathrm{s}}+\ldots+\mathrm{p}^{\mathrm{t}-1}-\mathrm{p}^{\mathrm{t}-2}+\mathrm{p}^{\mathrm{t}}-\mathrm{p}^{\mathrm{t}-1} \\
& =\mathrm{p}^{\mathrm{t}-}-\mathrm{p}^{\mathrm{s}-1} .
\end{aligned}
$$

Theorem 2.7 : Let $A_{i}$, for $1 \leq \mathrm{i} \leq \mathrm{m}-1$, be subsets of $\mathrm{Z}^{*}\left(\mathrm{Z}_{\mathrm{p}^{\mathrm{m}}}\right)$ which are defined in Definition 2.5. Then, for any $x, y \in Z^{*}\left(Z_{p^{m}}\right), x y=0$ if and only if $x \in A_{i}$ and $y \in A_{j}$ such that $\mathrm{i}+\mathrm{j} \leq \mathrm{m}$, for some $1 \leq \mathrm{i}, \mathrm{j} \leq \mathrm{m}-1$.

Proof : From Definition 2.5 we have $Z^{*}\left(Z_{p^{m}}\right)=U_{i=1}^{m-1} A_{i}$, where $A_{i}=\left\{k_{i} p^{m-i}\right.$ : $\left.\mathrm{k}_{\mathrm{i}}=1,2, \ldots, \mathrm{p}^{\mathrm{i}}-1 ; \mathrm{p} \nmid \mathrm{k}_{\mathrm{i}}\right\}$, for $1 \leq \mathrm{i} \leq \mathrm{m}-1$. Now, for any $1 \leq \mathrm{i}, \mathrm{j} \leq \mathrm{m}-1$, let $\mathrm{x} \in \mathrm{A}_{\mathrm{i}}$ and $y \in A_{j}$. Then, there exists two positive integers $k_{i}$ and $k_{j}$ such that $x=k_{i} p^{m-i}$ and $y=k_{j} p^{m-}$ $\mathrm{j}$, with $\mathrm{p} \nmid \mathrm{k}_{\mathrm{i}}, \mathrm{k}_{\mathrm{j}}$.

Now, if $x y=0$. Then, $x y=k_{i} p^{m-i} k_{j} p^{m-j}=k_{i} k_{j} p^{2 m-(i+j)} \equiv 0\left(\bmod p^{m}\right)$, and since $\mathrm{k}_{\mathrm{i}} \mathrm{k}_{\mathrm{j}} \not \equiv 0\left(\bmod \mathrm{p}^{\mathrm{m}}\right)$, therefore $\mathrm{p}^{2 \mathrm{~m}-(\mathrm{i}+\mathrm{j})} \equiv 0\left(\bmod \mathrm{p}^{\mathrm{m}}\right)$, and that means $\mathrm{p}^{\mathrm{m}}$ divides $\mathrm{p}^{2 \mathrm{~m}-(\mathrm{i}+\mathrm{j})}$, which implies that $2 m-(i+j) \geq m$, therefore $i+j \leq m$. 
Conversely: Let $x \in A_{i}$ and $y \in A_{j}$ such that $i+j \leq m$ for some $1 \leq i, j \leq m-1$, and suppose contrary that $x y \neq 0 \Rightarrow x y=k_{i} k_{j} p^{2 m-(i+j)} \not \equiv 0\left(\bmod p^{m}\right)$, and since, $p \nmid k_{i}, k_{j}$, therefore $p^{m} \nmid p^{2 m-(i+j)}$. Then, we get $2 m-(i+j)<m$, so that $2 m-m<i+j$, which implies that $\mathrm{i}+\mathrm{j}>\mathrm{m}$, this contradiction, therefore $\mathrm{xy}=0$.

From Theorem 2.7 and Lemma 2.6 we can give the general form of the graph $\Gamma\left(\mathrm{Z}_{\mathrm{p}} \mathrm{t}\right)$, where $\mathrm{t}=4,5$, as the following :

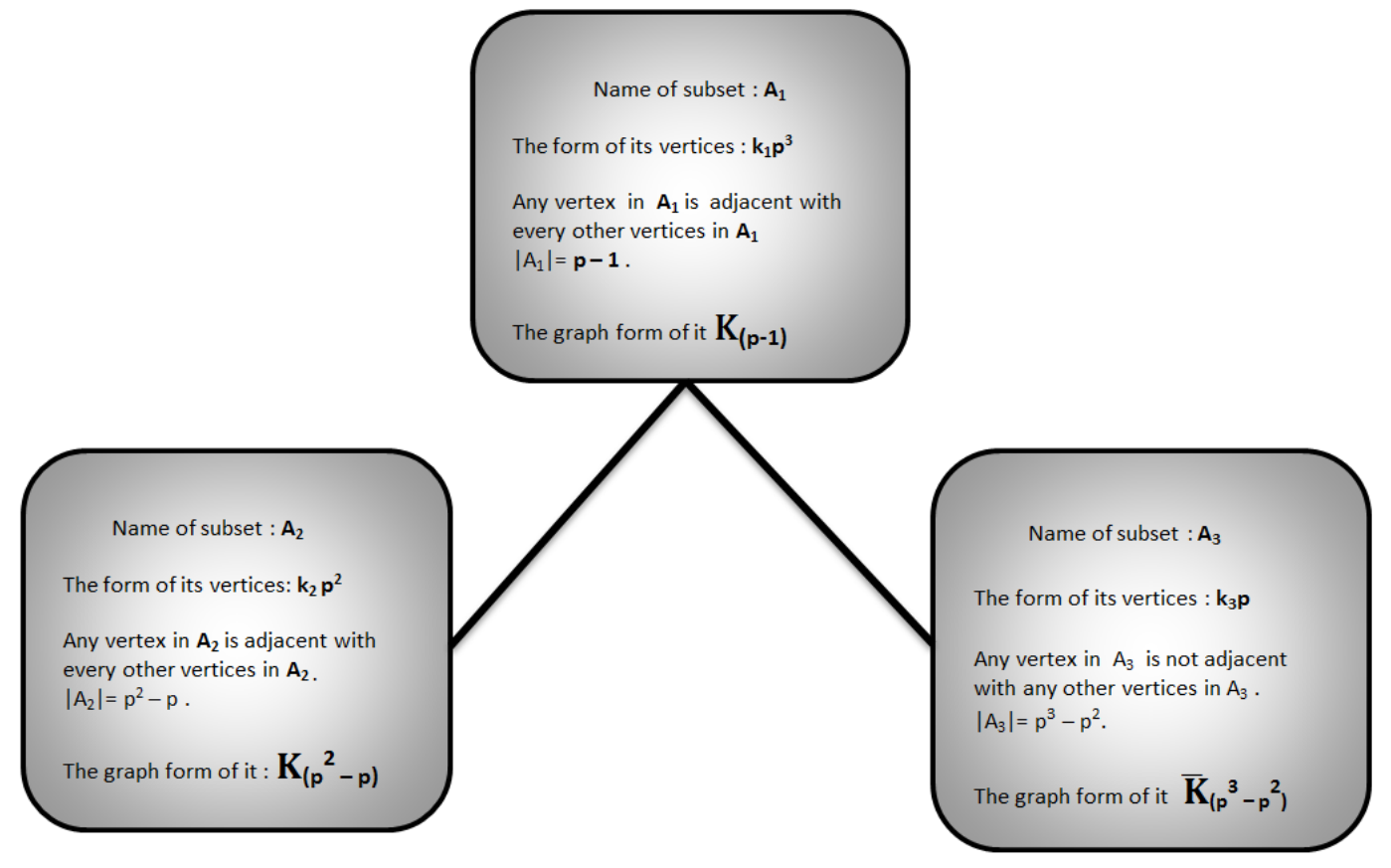

Figure 2.1 : The general form of the graph $\Gamma\left(Z_{p^{4}}\right) \cong K_{(p-1)}+\left(K_{\left(p^{2}-p\right)} \cup \bar{K}_{\left(p^{3}-p^{2}\right)}\right)$

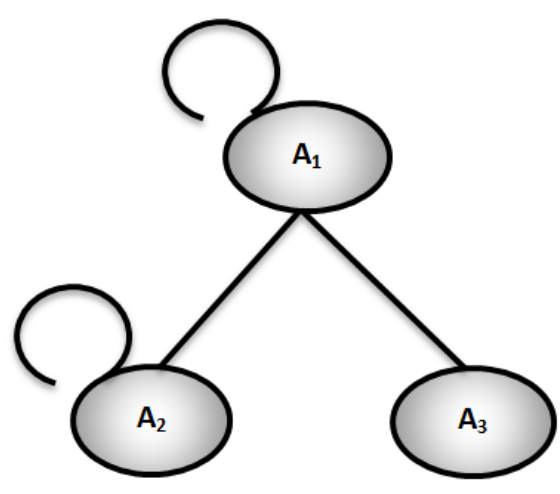

Figure 2.2

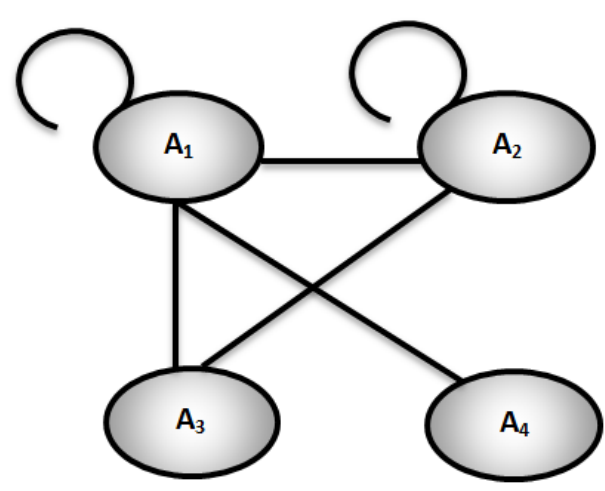

Figure 2.3

The general form of the graph $\Gamma\left(Z_{p^{4}}\right) \quad$ The general form of the graph $\Gamma\left(Z_{p^{5}}\right)$

We can now give the general form of the graph $\Gamma\left(Z_{p^{m}}\right)$ : 


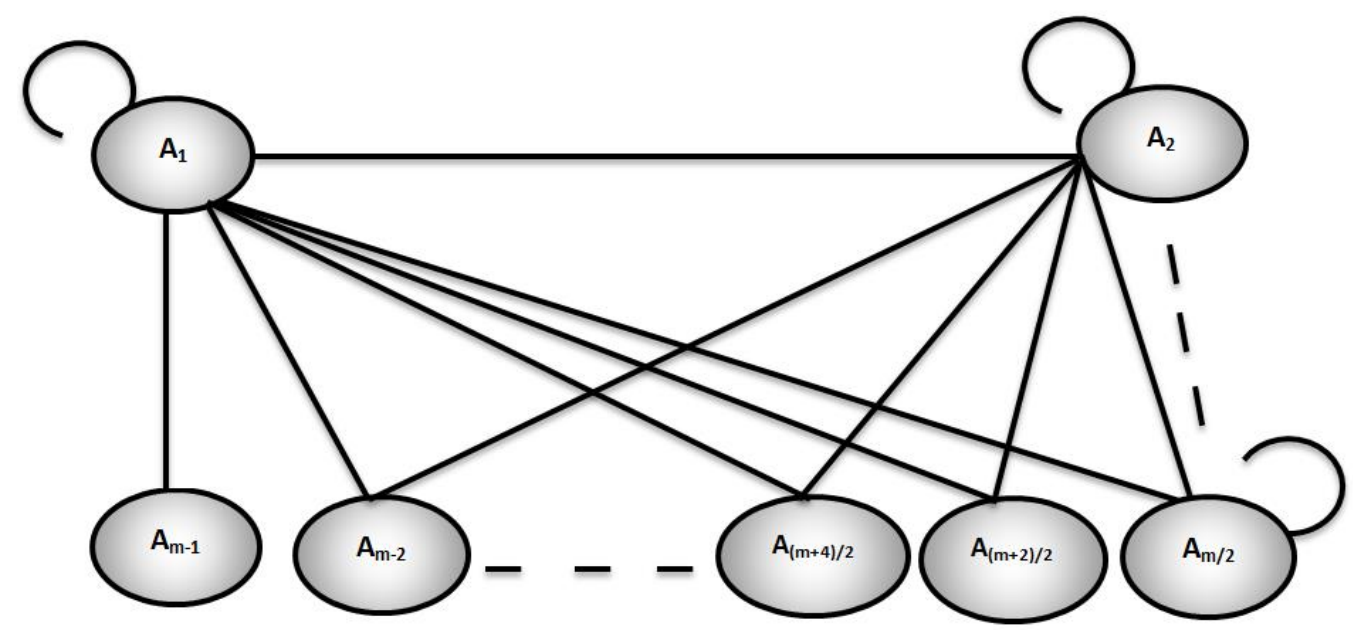

Figure 2.4: The general form of the graph $\Gamma\left(Z_{p^{m}}\right)$, where $m$ is an even number with $m \geq 6$.

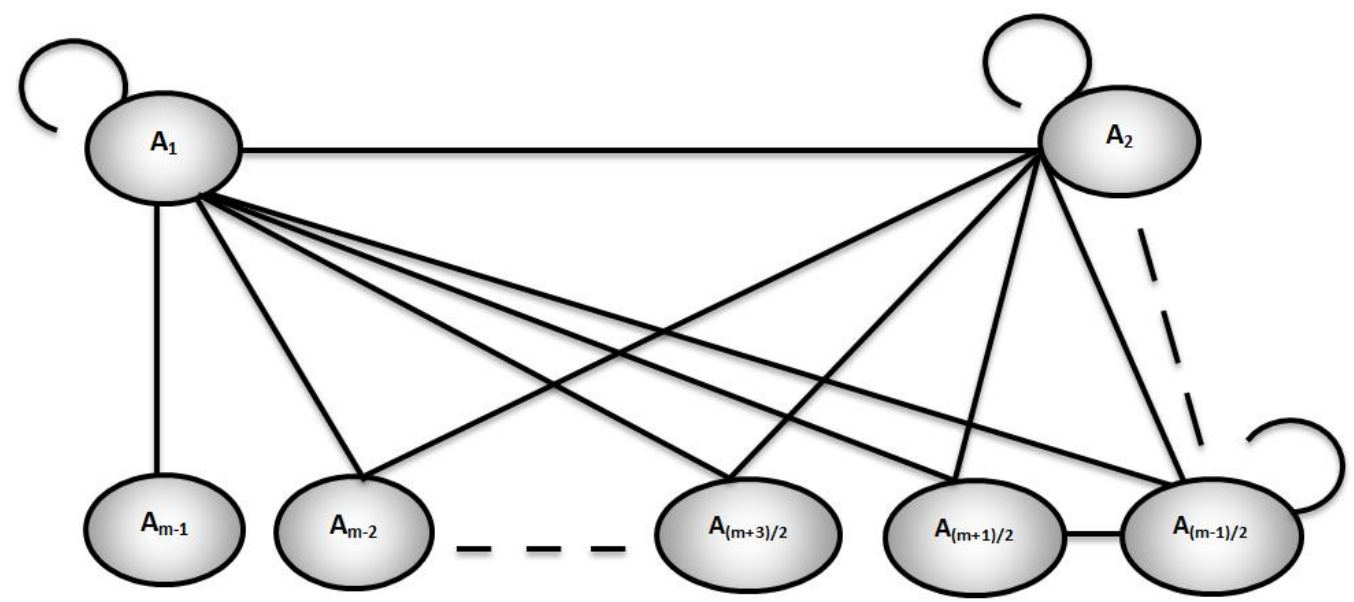

Figure 2.5 : The general form of the graph $\Gamma\left(Z_{p^{m}}\right)$, where $m$ is an odd number with $m \geq 7$.

Theorem 2.8 : The graph $\Gamma\left(\mathrm{Z}_{\mathrm{p}^{\mathrm{m}}}\right)$ is s-partite graph, where

$s= \begin{cases}p^{\frac{m-1}{2}} & ; \text { if } m \text { is an odd number } \\ p^{\frac{m}{2}}-1 & ; \text { if } m \text { is an even number }\end{cases}$

Proof : From Definition 2.5, we have $Z^{*}\left(Z_{p^{m}}\right)=U_{i=1}^{m-1} A_{i}$, where $A_{i}=\left\{k_{i} p^{m-i}, k_{i}=1,2, \ldots\right.$ , $\left.\mathrm{p}^{\mathrm{i}}-1 ; \mathrm{p} \nmid \mathrm{k}_{\mathrm{i}}\right\}$, for $1 \leq \mathrm{i} \leq \mathrm{m}-1$.

Suppose that $\mathrm{m}$ is an odd number, we see that by Theorem 2.7 , any two distinct vertices lie in $U_{i=1}^{\frac{m-1}{2}} A_{i}$ are adjacent because that $i+j \leq m$, for any $1 \leq i, j \leq \frac{m-1}{2}$, this means that, we cannot put the vertices of the sets $A_{1}, A_{2}, \ldots, \frac{A_{-1}}{2}$ in less than $\sum_{\mathrm{i}=1}^{\frac{\mathrm{m}-1}{2}}\left|\mathrm{~A}_{\mathrm{i}}\right|=\mathrm{p}^{\frac{\mathrm{m}-1}{2}}-1$ of partite sets. also by Theorem 2.7 we see that any vertex $\mathrm{x} \in$ $A_{\frac{m+1}{2}}$ is adjacent with every vertex of $U_{i=1}^{\frac{m-1}{2}} A_{i}$ because that $\frac{m+1}{2}+i \leq m$, for any $1 \leq i \leq$ $\frac{m-1}{2}$, so that $x$ is not adjacent with any other vertex in $\frac{A m+1}{2}$ because that $2\left(\frac{m+1}{2}\right)>m$, therefore we must consider new partite set, say $\mathrm{V}$, contains the vertices of $\frac{A_{m+1}}{2}$, in this case, we cannot put the vertices of the sets $A_{1}, A_{2}, \ldots, A_{\frac{m+1}{2}}$, in less than $\left(p^{\frac{m-1}{2}}-\right.$ 
$1)+1=p^{\frac{m-1}{2}}$ of partite sets. Now, if we can put the vertices of $U_{i=\frac{m+3}{2}}^{m-1} A_{i}$ in $V$, then the theorem hold, that is : by Theorem 2.7 we see that any two distinct vertices in $U_{i=\frac{m+3}{2}}^{m-1} A_{i}$ are not adjacent because that $i+j>m$ for any $\frac{m+3}{2} \leq i, j \leq m-1$, so that any vertex in $V$ is not adjacent with every vertex of $\bigcup_{i=\frac{m+3}{2}}^{m-1} A_{i}$ because that $\frac{m+1}{2}+i>$ $\mathrm{m}$, for any $\frac{\mathrm{m}+3}{2} \leq \mathrm{i} \leq \mathrm{m}-1$, and this shows that we cannot put the vertices of $\mathrm{Z}^{*}\left(\mathrm{Z}_{\mathrm{p}^{\mathrm{m}}}\right)=\cup_{\mathrm{i}=1}^{\mathrm{m}-1} \mathrm{~A}_{\mathrm{i}}$ in less than $\mathrm{p}^{\frac{\mathrm{m}-1}{2}}$ of partite sets, therefore $\Gamma\left(\mathrm{Z}_{\mathrm{p}^{\mathrm{m}}}\right)$ is $\mathrm{p}^{\frac{\mathrm{m}-1}{2}}$-partite graph.

Now, let $\mathrm{m}$ be an even integer number, similarly we cannot put the vertices of the set $U_{i=1}^{\frac{m}{2}} A_{i}$ in less than $\sum_{i=1}^{\frac{m}{2}}\left|A_{i}\right|=p^{\frac{m}{2}}-1$ of partite sets, say $V_{1}, V_{2}, \ldots, V_{p^{\frac{m}{2}}-1}$, each of these partite sets contains only one vertex of the set $U_{i=1}^{\frac{m}{2}} A_{i}$, suppose that the partite set $V_{p^{\frac{m}{2}-1}}$ contains one of the vertices of the set $A_{\frac{m}{2}}$, and we are going to show that we can put the vertices of the set $U_{i=\frac{m+2}{2}}^{m-1} A_{i}$ in the partite set $V_{p^{\frac{m}{2}-1}}$, that is : by Theorem 2.7 we see that any two distinct vertices in the set $U_{i=\frac{m+2}{2}}^{m-1} A_{i}$ are not adjacent because that $i+j>m$ for any $\frac{m+2}{2} \leq i, j \leq m-1$, so that any vertex of the set $U_{i=\frac{m+2}{2}}^{m-1} A_{i}$ is not adjacent with every vertex of the set $A_{\frac{m}{2}}$ because that $\frac{m}{2}+i>n$ for any $\frac{m+2}{2} \leq i \leq m-$ 1 , and this shows we can put the vertices of the set $U_{i=\frac{m+2}{2}}^{m-1} A_{i}$ in the partite set $V_{p^{\frac{m}{2}}-1}$, therefore we cannot put the vertices of $Z^{*}\left(Z_{p^{m}}\right)=\bigcup_{i=1}^{m-1} A_{i}$ in less than $p^{\frac{m}{2}}-1$ of partite sets, hence $\Gamma\left(\mathrm{Z}_{\mathrm{p}^{\mathrm{m}}}\right)$ is $\left(\mathrm{p}^{\frac{\mathrm{m}}{2}}-1\right)$-partite graph.

Lemma 2.9 [7] : Let $\mathrm{G}$ be a connected graph of order $r$. Then $\sum_{\mathrm{i}=0}^{\operatorname{diam}(\mathrm{G})} \mathrm{d}(\mathrm{G}, \mathrm{i})=\frac{1}{2} \mathrm{r}(\mathrm{r}+1)$.

Now, we give the main result in this section.

Theorem 2.10: $\mathrm{H}\left(\Gamma\left(\mathrm{Z}_{\mathrm{p}^{\mathrm{m}}}\right) ; \mathrm{x}\right)=\mathrm{a}_{0}+\mathrm{a}_{1} \mathrm{x}+\mathrm{a}_{2} \mathrm{x}^{2}$, where $\mathrm{a}_{0}=\mathrm{p}^{\mathrm{m}-1}-1$, $\mathrm{a}_{1}=\frac{1}{2}\left[(\mathrm{~m}-1) \mathrm{p}^{\mathrm{m}}-\mathrm{m} \mathrm{p}^{\mathrm{m}-1}-\mathrm{p}^{\left\lfloor\frac{\mathrm{m}}{2}\right\rfloor}+2\right]$, and $\mathrm{a}_{2}=\frac{1}{2}\left[\mathrm{p}^{2(\mathrm{~m}-1)}-(\mathrm{m}-1) \mathrm{p}^{\mathrm{m}}+(\mathrm{m}-3) \mathrm{p}^{\mathrm{m}-1}+\mathrm{p}^{\left\lfloor\frac{\mathrm{m}}{2}\right\rfloor}\right]$.

Proof : When $\mathrm{m}=2$, we have $\Gamma\left(\mathrm{Z}_{\mathrm{p}^{2}}\right) \cong \mathrm{K}_{\mathrm{p}-1}$, and the theorem is true in this case.

Now, suppose that $m \geq 3$, since $Z_{p^{m}}$ is a local ring, then by

Theorem 2.3.], there is a vertex adjacent with every other vertices in $\Gamma\left(\mathrm{Z}_{\mathrm{p}^{\mathrm{m}}}\right)$, this means that $\operatorname{diam}\left(\Gamma\left(\mathrm{Z}_{\mathrm{p}^{\mathrm{m}}}\right)\right)=2$, therefore $\mathrm{H}\left(\Gamma\left(\mathrm{Z}_{\mathrm{p}^{\mathrm{m}}}\right) ; \mathrm{x}\right)=\mathrm{a}_{0}+\mathrm{a}_{1} \mathrm{x}+\mathrm{a}_{2} \mathrm{x}^{2}$, where $\mathrm{a}_{\mathrm{i}}=\mathrm{d}\left(\Gamma\left(\mathrm{Z}_{\mathrm{p}^{\mathrm{m}}}\right), \mathrm{i}\right.$ ), for $\mathrm{i}=0,1,2$.

To find a 0 , by Lemma 2.1 we have $\mathrm{a}_{0}=\mathrm{d}\left(\Gamma\left(\mathrm{Z}_{\mathrm{p}^{\mathrm{m}}}\right), 0\right)=\left|\mathrm{Z}^{*}\left(Z_{\mathrm{p}^{\mathrm{m}}}\right)\right|=\frac{\mathrm{p}^{\mathrm{m}}}{\mathrm{p}}-1=\mathrm{p}^{\mathrm{m}-1}-1$.

To find $\mathrm{a}_{1}$, suppose that $\mathrm{m}$ be an odd number, and let $\mathrm{x}, \mathrm{y} \in \mathrm{Z}^{*}\left(\mathrm{Z}_{\mathrm{p}^{\mathrm{m}}}\right)$, since $Z^{*}\left(Z_{p^{m}}\right)=U_{i=1}^{m-1} A_{i}$, then by Theorem 2.7 we see that $d(x, y)=1$ (i.e. $\left.x y=0\right)$ if and only if 
$x \in A_{i}$ and $y \in A_{j}$ such that $i+j \leq m$, for some

$1 \leq \mathrm{i}, \mathrm{j} \leq \mathrm{m}-1$, and this holds if and only if one of the following two cases holds :

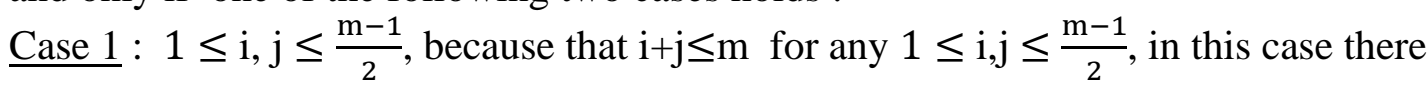
are $\mathrm{m}_{1}$ edges where

$\mathrm{m}_{1}=\left(\begin{array}{c}\sum_{\mathrm{i}=1}^{\frac{\mathrm{m}-1}{2}}\left|\mathrm{~A}_{\mathrm{i}}\right| \\ 2\end{array}\right)=\left(\begin{array}{c}\mathrm{p}^{\frac{\mathrm{m}-1}{2}}-1 \\ 2\end{array}\right)=\frac{1}{2}\left(\mathrm{p}^{\frac{\mathrm{m}-1}{2}}-1\right)\left(\mathrm{p}^{\frac{\mathrm{m}-1}{2}}-2\right) \ldots(*)$.

Case $2: 1 \leq \mathrm{i} \leq \frac{\mathrm{m}-1}{2}$ and $\frac{\mathrm{m}+1}{2} \leq \mathrm{j} \leq \mathrm{m}-\mathrm{i}$, since that $\mathrm{i}+\mathrm{j} \leq \mathrm{m}$ for any $\quad 1 \leq \mathrm{i} \leq \frac{\mathrm{m}-1}{2}$ and $\frac{m+1}{2} \leq \mathrm{j} \leq \mathrm{m}-\mathrm{i}$, in this case there are $\mathrm{m}_{2}$ edges where $\mathrm{m}_{2}=\sum_{\mathrm{i}=1}^{\frac{\mathrm{m}-1}{2}}\left(\left|\mathrm{~A}_{\mathrm{i}}\right| \sum_{\mathrm{j}=\frac{\mathrm{m}+1}{2}}^{\mathrm{m}-\mathrm{i}}\left|\mathrm{A}_{\mathrm{j}}\right|\right)$, since $\left|\mathrm{A}_{\mathrm{i}}\right|=\mathrm{p}^{\mathrm{i}}-\mathrm{p}^{\mathrm{i}-1}$, for each $1 \leq \mathrm{i} \leq \mathrm{m}-1$, and by using Lemma 2.6 we get :

$$
\begin{aligned}
\mathrm{m}_{2} & =\sum_{\mathrm{i}=1}^{\frac{\mathrm{m}-1}{2}}\left(\mathrm{p}^{\mathrm{i}}-\mathrm{p}^{\mathrm{i}-1}\right)\left(\mathrm{p}^{\mathrm{m}-\mathrm{i}}-\mathrm{p}^{\frac{\mathrm{m}-1}{2}}\right) \\
& =\sum_{\mathrm{i}=1}^{\frac{\mathrm{m}-1}{2}} \mathrm{p}^{\mathrm{i}-1}(\mathrm{p}-1)\left(\mathrm{p}^{\mathrm{m}-\mathrm{i}}-\mathrm{p}^{\frac{\mathrm{m}-1}{2}}\right)=\sum_{\mathrm{i}=1}^{\frac{\mathrm{m}-1}{2}}(\mathrm{p}-1)\left(\mathrm{p}^{\mathrm{m}-1}-\mathrm{p}^{\frac{\mathrm{m}-3}{2}} \mathrm{p}^{\mathrm{i}}\right) \\
& =\sum_{\mathrm{i}=1}^{\frac{\mathrm{m}-1}{2}} \mathrm{p}^{\mathrm{m}-1}(\mathrm{p}-1)-\mathrm{p}^{\frac{\mathrm{m}-3}{2}}(\mathrm{p}-1) \sum_{\substack{\mathrm{i}=1 \\
\frac{\mathrm{m}-1}{2}}} \mathrm{p}^{\mathrm{i}} \\
& =\frac{\mathrm{m}-1}{2} \mathrm{p}^{\mathrm{m}-1}(\mathrm{p}-1)-\mathrm{p}^{\frac{\mathrm{m}-3}{2}}(\mathrm{p}-1) \sum_{\mathrm{i}=1}^{\frac{\mathrm{m}-1}{2}} \mathrm{p}^{\mathrm{i}}, \text { and since }\left\{\mathrm{p}^{\mathrm{i}}\right\}_{\mathrm{i}=1}^{\frac{\mathrm{m}-1}{2}} \text { is a geometric sequence, }
\end{aligned}
$$
therefore we can use $\sum_{i=1}^{k} a^{i}=\frac{a^{k+1}-a}{a-1}$ where $a$ be any real number and $k$ is any positive integer, hence we have : $\quad \mathrm{m}_{2}=\frac{\mathrm{m}-1}{2} \mathrm{p}^{\mathrm{m}-1}(\mathrm{p}-1)-\mathrm{p}^{\frac{\mathrm{m}-3}{2}}(\mathrm{p}-1)$

$$
\begin{aligned}
& \frac{\mathrm{p}^{\frac{\mathrm{m}+1}{2}}-\mathrm{p}}{(\mathrm{p}-1)} \\
& \quad=\frac{\mathrm{m}-1}{2} \mathrm{p}^{\mathrm{m}-1}(\mathrm{p}-1)-\mathrm{p}^{\frac{\mathrm{m}-1}{2}}\left(\mathrm{p}^{\frac{\mathrm{m}-1}{2}}-1\right) \ldots(* *) .
\end{aligned}
$$

Now, from $(*)$ and $(* *)$, we get

$$
\begin{aligned}
\mathrm{a}_{1} & =\mathrm{m}_{1}+\mathrm{m}_{2}=\frac{1}{2}\left(\mathrm{p}^{\frac{\mathrm{m}-1}{2}}-1\right)\left(\mathrm{p}^{\frac{\mathrm{m}-1}{2}}-2\right)+\frac{\mathrm{m}-1}{2} \mathrm{p}^{\mathrm{m}-1}(\mathrm{p}-1)-\mathrm{p}^{\frac{\mathrm{m}-1}{2}}\left(\mathrm{p}^{\frac{\mathrm{m}-1}{2}}-1\right) \\
& =\frac{1}{2}\left[(\mathrm{~m}-1) \mathrm{p}^{\mathrm{m}}-\mathrm{m} \mathrm{p}^{\mathrm{m}-1}-\mathrm{p}^{\frac{\mathrm{m}-1}{2}}+2\right] .
\end{aligned}
$$

Similarly, when an $\mathrm{m}$ be an even number we get that

$$
\left[(\mathrm{m}-1) \mathrm{p}^{\mathrm{m}}-\mathrm{m} \mathrm{p}^{\mathrm{m}-1}-\mathrm{p}^{\frac{\mathrm{m}}{2}}+2\right] \text {. }
$$

Hence $\mathrm{a}_{1}=\frac{1}{2}\left[(\mathrm{~m}-1) \mathrm{p}^{\mathrm{m}}-\mathrm{m} \mathrm{p}^{\mathrm{m}-1}-\mathrm{p}^{\left\lfloor\frac{\mathrm{m}}{2}\right\rfloor}+2\right]$.

Next, to find $a_{2}$ we shall use lemma 2.9, and we get :

$$
\begin{aligned}
\mathrm{a}_{2} & =\frac{1}{2} \mathrm{a}_{0}\left(\mathrm{a}_{0}+1\right)-\mathrm{a}_{0}-\mathrm{a}_{1} \\
& =\frac{1}{2}\left(\mathrm{p}^{\mathrm{m}-1}-1\right) \mathrm{p}^{\mathrm{m}-1}-\left(\mathrm{p}^{\mathrm{m}-1}-1\right)-\frac{1}{2}\left[(\mathrm{~m}-1) \mathrm{p}^{\mathrm{m}}-\mathrm{m} \mathrm{p}^{\mathrm{m}-1}-\mathrm{p}^{\left\lfloor\frac{\mathrm{m}}{2}\right\rfloor}+2\right] \\
& =\frac{1}{2}\left[\mathrm{p}^{2(\mathrm{~m}-1)}-(\mathrm{m}-1) \mathrm{p}^{\mathrm{m}}+(\mathrm{m}-3) \mathrm{p}^{\mathrm{m}-1}+\mathrm{p}^{\left[\frac{\mathrm{m}}{2}\right\rfloor}\right] .
\end{aligned}
$$

Corollary 2.11: $\mathbf{W}\left(\Gamma\left(\mathrm{Z}_{\mathrm{p}^{\mathrm{m}}}\right)\right)=\frac{1}{2}\left[2 \mathrm{p}^{2(\mathrm{~m}-1)}-(\mathrm{m}-1) \mathrm{p}^{\mathrm{m}}+(\mathrm{m}-6) \mathrm{p}^{\mathrm{m}-1}+\mathrm{p}^{\left\lfloor\frac{\mathrm{m}}{2}\right\rfloor}+2\right]$.

\section{Hosoya Polynomial and Wiener Index of $\Gamma\left(Z_{p^{m}}\right)$.}

In this section, we find the Hosoya polynomial and the Wiener index of $\Gamma\left(\mathrm{Z}_{\mathrm{p}^{\mathrm{m}_{\mathrm{q}}}}\right)$. First, we shall give the following lemma : 
Lemma 3.1 : The number of all non-zero zero-divisors of a ring $\mathrm{Z}_{\mathrm{p}^{\mathrm{m}}}$ is $(\mathrm{p}+\mathrm{q}-1) \mathrm{p}^{\mathrm{m}-1}-1$.

Proof : Since, $\mathrm{p}$ and $\mathrm{q}$ are distinct prime numbers, then clearly

$\mathrm{Z}(\mathrm{R})=(\mathrm{p}) \mathrm{U}(\mathrm{q})$, therefore $\mathrm{Z}^{*}(\mathrm{R})=\{(\mathrm{p}) \mathrm{U}(\mathrm{q})\} \backslash\{0\}$.

Now, let $x \in Z^{*}(R)$, then either $x \in(p)$ or $x \in(q)$ with $x \notin(p q)$, so by Lemma 2.1 we get :

$$
\begin{aligned}
\left|Z^{*}(R)\right| & =\left(\frac{p^{m} \mathrm{q}}{p}-1\right)+\left(\frac{p^{m} \mathrm{q}}{q}-1\right)-\left(\frac{p^{m} \mathrm{q}}{p q}-1\right) \\
& =\left(\mathrm{p}^{\mathrm{m}-1} \mathrm{q}-1\right)+\left(\mathrm{p}^{\mathrm{m}}-1\right)-\left(\mathrm{p}^{\mathrm{m}-1}-1\right) \\
& =\mathrm{p}^{\mathrm{m}-1} \mathrm{q}-1+\mathrm{p}^{\mathrm{m}}-1-\mathrm{p}^{\mathrm{m}-1}+1 \\
& =(\mathrm{p}+\mathrm{q}-1) \mathrm{p}^{\mathrm{m}-1}-1 .
\end{aligned}
$$

Definition 3.2 : Let $\mathrm{Z}_{\mathrm{p}} \mathrm{m}_{\mathrm{q}}$ be the ring of integers modulo $\mathrm{p}^{\mathrm{m}} \mathrm{q}$, then we can write :

$Z^{*}\left(Z_{p^{m}}\right)=U_{i=1}^{m}\left(B_{i} \cup C_{i}\right)$, where $B_{i}$ and $C_{i}$, are disjoint subsets of $Z^{*}\left(Z_{p^{m}}\right)$, for $1 \leq i \leq$ $\mathrm{m}$, which are defined as follows :

$$
\begin{aligned}
& \mathrm{B}_{1}=\left(\mathrm{p}^{\mathrm{m}-1} \mathrm{q}\right) \backslash\{0\}, \mathrm{B}_{2}=\left(\mathrm{p}^{\mathrm{m}-2} \mathrm{q}\right) \backslash\left\{\mathrm{B}_{1} \cup\{0\}\right\}, \\
& \mathrm{B}_{3}=\left(\mathrm{p}^{\mathrm{m}-3} \mathrm{q}\right) \backslash\left\{\mathrm{B}_{1} \cup \mathrm{B}_{2} \cup\{0\}\right\}, \ldots, \\
& \mathrm{B}_{\mathrm{m}}=(\mathrm{q}) \backslash\left\{\left\{\cup_{\mathrm{i}=1}^{\mathrm{m}-1} \mathrm{~B}_{\mathrm{i}}\right\} \cup\{0\}\right\}, \text { and } \\
& \mathrm{C}_{1}=\left(\mathrm{p}^{\mathrm{m}}\right) \backslash\{0\}, \mathrm{C}_{2}=\left(\mathrm{p}^{\mathrm{m}-1}\right) \backslash\left\{\mathrm{B}_{1} \cup \mathrm{C}_{1} \cup\{0\},\right. \\
& \mathrm{C}_{3}=\left(\mathrm{p}^{\mathrm{m}-2}\right) \backslash\left\{\mathrm{B}_{1} \cup \mathrm{C}_{1} \cup \mathrm{B}_{2} \cup \mathrm{C}_{2} \cup\{0\}\right\}, \ldots, \\
& \left.\mathrm{C}_{\mathrm{m}}=(\mathrm{p})\right) \backslash\left\{\left\{\cup_{\mathrm{i}=1}^{\mathrm{m}-1}\left(\mathrm{~B}_{\mathrm{i}} \cup \mathrm{C}_{\mathrm{i}}\right)\right\} \cup\{0\}\right\} .
\end{aligned}
$$

Notice that, by Lemma 2.1 we get :

$\left|\mathrm{B}_{\mathrm{i}}\right|=\mathrm{p}^{\mathrm{i}}-\mathrm{p}^{\mathrm{i}-1}$, for any $1 \leq \mathrm{i} \leq \mathrm{m},\left|\mathrm{C}_{1}\right|=(\mathrm{q}-1)$ and $\left|\mathrm{C}_{\mathrm{i}}\right|=\left(\mathrm{p}^{\mathrm{i}-1}-\mathrm{p}^{\mathrm{i}-2}\right)(\mathrm{q}-1)$, for all $2 \leq \mathrm{i} \leq \mathrm{m}$, also we can write :

$\mathrm{B}_{\mathrm{i}}=\left\{\mathrm{k}_{\mathrm{i}} \mathrm{p}^{\mathrm{m}-\mathrm{i}} \mathrm{q}: \mathrm{k}_{\mathrm{i}}=1,2, \ldots, \mathrm{p}^{\mathrm{i}}-1 ; \mathrm{p} \nmid \mathrm{k}_{\mathrm{i}}\right\}$, and $\quad \mathrm{C}_{\mathrm{i}}=\left\{\mathrm{k}_{\mathrm{i}} \mathrm{p}^{\mathrm{m}-\mathrm{i}+1}: \mathrm{k}_{\mathrm{i}}=1,2, \ldots, \mathrm{p}^{\mathrm{i}-1} \mathrm{q}-1 ; \mathrm{q} \nmid \mathrm{k}_{\mathrm{i}}\right\}$, for any $1 \leq \mathrm{i} \leq \mathrm{m}$.

\section{Remarks :}

(1) $\sum_{\mathrm{i}=1}^{\mathrm{m}}\left|\mathrm{B}_{\mathrm{i}}\right|=\mathrm{p}^{\mathrm{m}}-1$.

(2) $\sum_{\mathrm{i}=1}^{\mathrm{m}}\left|\mathrm{C}_{\mathrm{i}}\right|=\mathrm{p}^{\mathrm{m}-1}(\mathrm{q}-1)$.

(3) $\left|\mathrm{C}_{\mathrm{i}}\right|=(\mathrm{q}-1)\left|\mathrm{B}_{\mathrm{i}-1}\right|$, for any $2 \leq \mathrm{i} \leq \mathrm{m}$.

(4) $\left|A_{i}\right|=\left|B_{i}\right|$, for any $1 \leq i \leq m-1$, where $A_{i}$, for all $1 \leq i \leq m-1$, be subsets of $\mathrm{Z}^{*}\left(\mathrm{Z}_{\mathrm{p}^{\mathrm{m}}}\right)$ which are defined in Definition 2.5 .

Lemma 3.3 : Let $B_{i}$ and $C_{i}$, for all $1 \leq i \leq m$, be subsets of $Z^{*}\left(Z_{p^{m}}\right)$ which are defined in Definition 3.2 then :

1- If $\mathrm{s}$ and $\mathrm{t}$ are two integers with $1 \leq \mathrm{s} \leq \mathrm{t} \leq \mathrm{m}$, then $\sum_{\mathrm{i}=\mathrm{s}}^{\mathrm{t}}\left|\mathrm{B}_{\mathrm{i}}\right|=\mathrm{p}^{\mathrm{t}}-\mathrm{p}^{\mathrm{s}-1}$.

2- If $\mathrm{t}$ be an integer with $1 \leq \mathrm{t} \leq \mathrm{m}$, then $\sum_{\mathrm{i}=1}^{\mathrm{t}}\left|\mathrm{C}_{\mathrm{i}}\right|=(\mathrm{q}-1) \mathrm{p}^{\mathrm{t}-1}$.

3- If $\mathrm{s}$ and $\mathrm{t}$ are two integers with $2 \leq \mathrm{s} \leq \mathrm{t} \leq \mathrm{m}$, then $\sum_{\mathrm{i}=\mathrm{s}}^{\mathrm{t}}\left|\mathrm{C}_{\mathrm{i}}\right|=(\mathrm{q}-1)\left(\mathrm{p}^{\mathrm{t}-1}-\mathrm{p}^{\mathrm{s}-2}\right)$.

Proof : By the same method of a proof of Lemma 2.6.

Theorem 3.4 : Let $\mathrm{B}_{\mathrm{i}}$ and $\mathrm{C}_{\mathrm{i}}$, for $1 \leq \mathrm{i} \leq \mathrm{m}$, be subsets of $\mathrm{Z}^{*}\left(\mathrm{Z}_{\mathrm{p}^{\mathrm{m}} \mathrm{q}}\right)$ which are defined

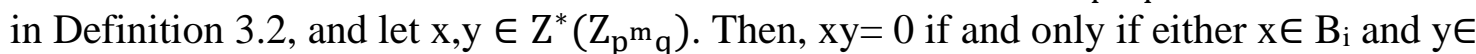
$B_{j}$ with $i+j \leq m$, or $x \in B_{i}$ and $y \in C_{j}$ with $i+j \leq m+1$, for some $1 \leq \mathrm{i}, \mathrm{j} \leq \mathrm{m}$.

Proof : From the Definition 3.2, we have $Z^{*}\left(Z_{p^{m}}\right)=\bigcup_{i=1}^{m}\left(B_{i} \cup C_{i}\right)$. Now, let $x, y \in$ $\mathrm{Z}^{*}\left(\mathrm{Z}_{\mathrm{p}^{\mathrm{m}_{\mathrm{q}}}}\right)$ such that $\mathrm{xy}=0$, since $\mathrm{x}, \mathrm{y} \in \mathrm{U}_{\mathrm{i}=1}^{\mathrm{m}}\left(\mathrm{B}_{\mathrm{i}} \cup \mathrm{C}_{\mathrm{i}}\right)$, then there are two cases :

Case 1: $x \in B_{i}$ and $y \in B_{j}$ for some $1 \leq \mathrm{i}, \mathrm{j} \leq \mathrm{m}$, in this case, there are positive integers $\mathrm{k}_{\mathrm{i}}$ and $\mathrm{k}_{\mathrm{j}}$ with $\mathrm{p} \nmid \mathrm{k}_{\mathrm{i}}, \mathrm{k}_{\mathrm{j}}$, such that $\mathrm{x}=\mathrm{k}_{\mathrm{i}} \mathrm{p}^{\mathrm{m}-\mathrm{i}} \mathrm{q}$ and $\mathrm{y}=\mathrm{k}_{\mathrm{j}} \mathrm{p}^{\mathrm{m}-\mathrm{j}} \mathrm{q}$, for some $1 \leq \mathrm{i}, \mathrm{j} \leq \mathrm{m}$, since $x y=0$ by hypothesis, then we get $x y=\left(k_{i} k_{j}\right) p^{2 m-(i+j)} q^{2} \equiv 0\left(\bmod p^{m} q\right)$, since $p \nmid k_{i}, k_{j}$, 
therefore $\mathrm{p}^{2 \mathrm{~m}-(\mathrm{i}+\mathrm{j})} \mathrm{q}^{2} \equiv 0\left(\bmod \mathrm{p}^{\mathrm{m}} \mathrm{q}\right)$, this means that $\mathrm{p}^{2 \mathrm{~m}-(\mathrm{i}+\mathrm{j})}$ is divisible by $\mathrm{p}^{\mathrm{m}}$. Therefore $2 \mathrm{~m}-(\mathrm{i}+\mathrm{j}) \geq \mathrm{m}$, hence $\mathrm{i}+\mathrm{j} \leq \mathrm{m}$.

Case 2: $x \in B_{i}$, and $y \in C_{j}$ for some $1 \leq \mathrm{i}, \mathrm{j} \leq \mathrm{m}$, in this case, there are positive integers $\mathrm{k}_{\mathrm{i}}$ and $\mathrm{k}_{\mathrm{j}}$ with $\mathrm{p} \nmid \mathrm{k}_{\mathrm{i}}$ and $\mathrm{q} \nmid \mathrm{k}_{\mathrm{j}}$, such that $\mathrm{x}=\mathrm{k}_{\mathrm{i}} \mathrm{p}^{\mathrm{m}-\mathrm{i}} \mathrm{q}$ and $\mathrm{y}=\mathrm{k}_{\mathrm{j}} \mathrm{p}^{\mathrm{m}-\mathrm{j}+1}$, for some $1 \leq \mathrm{i}, \mathrm{j} \leq \mathrm{m}$, since $x y=0$ by hypothesis, then $x y=\left(k_{i} k_{j}\right) p^{2 m-(i+j)+1} q \equiv 0\left(\bmod p^{m} q\right)$, Since $p \nmid k_{i}$ and $\mathrm{q} \nmid \mathrm{k}_{\mathrm{j}}$, therefore $\mathrm{p}^{2 \mathrm{~m}-(\mathrm{i}+\mathrm{j})} \mathrm{q} \equiv 0\left(\bmod \mathrm{p}^{\mathrm{m}} \mathrm{q}\right)$, this means that $\mathrm{p}^{2 \mathrm{~m}-(\mathrm{i}+\mathrm{j})}$ is divisible by $\mathrm{p}^{\mathrm{m}}$, therefore $2 \mathrm{~m}-(\mathrm{i}+\mathrm{j})+1 \geq \mathrm{m}$, hence $\mathrm{i}+\mathrm{j} \leq \mathrm{m}+1$.

Finally, we see that when $x \in C_{i}$ and $y \in C_{j}$, then $x y \neq 0$ for any $1 \leq i, j \leq m$.

From previous, we get that if $x y=0$, then either $x \in B_{i}$ and $y \in B_{j}$ with $i+j \leq m$, or $x \in B_{i}$ and $y \in C_{j}$ with $i+j \leq m+1$, for some $1 \leq \mathrm{i}, j \leq m$.

Conversely : Let $x \in B_{i}$ and $y \in B_{j}$ for some $1 \leq i, j \leq m$, such that $i+j \leq m$, and suppose contrary that $x y \neq 0$,we get $x y=\left(k_{i} k_{j}\right) p^{2 m-(i+j)} q^{2} \not \equiv 0\left(\bmod p^{m} q\right)$, since $p \nmid k_{i}, k_{j}$ and $q$ divides $\mathrm{q}^{2}$ then $\quad \mathrm{p}^{2 \mathrm{~m}-(\mathrm{i}+\mathrm{j})}$ is not divisible by $\mathrm{p}^{\mathrm{m}}$, therefore $2 \mathrm{~m}-(\mathrm{i}+\mathrm{j})<\mathrm{m} \Rightarrow \mathrm{i}+\mathrm{j}>\mathrm{m}$, this contradiction, therefore must be $\mathrm{xy}=0$.

Now, let $x \in B_{i}$ and $y \in C_{j}$ for some $1 \leq i, j \leq m$, such that $i+j \leq m+1$, and suppose contrary that $x y \neq 0$,we get $\mathrm{xy}=\left(\mathrm{k}_{\mathrm{i}} \mathrm{k}_{\mathrm{j}}\right) \mathrm{p}^{2 \mathrm{~m}-}$ ${ }^{(i+j)+1} \mathrm{q} \not \equiv 0\left(\bmod \mathrm{p}^{\mathrm{m}} \mathrm{q}\right)$, and since $\mathrm{p} \nmid \mathrm{k}_{\mathrm{i}}$ and $\mathrm{q} \nmid \mathrm{k}_{\mathrm{j}}$ then $\mathrm{p}^{2 \mathrm{~m}-(\mathrm{i}+\mathrm{j})+1}$ is not divisible by $\mathrm{p}^{\mathrm{m}}$, therefore $2 \mathrm{~m}-(\mathrm{i}+\mathrm{j})+1<\mathrm{m} \Rightarrow \mathrm{i}+\mathrm{j}>\mathrm{m}+1$, also this is a contradiction, therefore must be $\mathrm{xy}=0$.

From Theorem 3.4 and Lemma 3.3, we can give the general form of the graph $\Gamma\left(\mathrm{Z}_{\mathrm{p}^{\mathrm{t}} \mathrm{q}}\right)$, where $\mathrm{t}=3,4$, as follows :

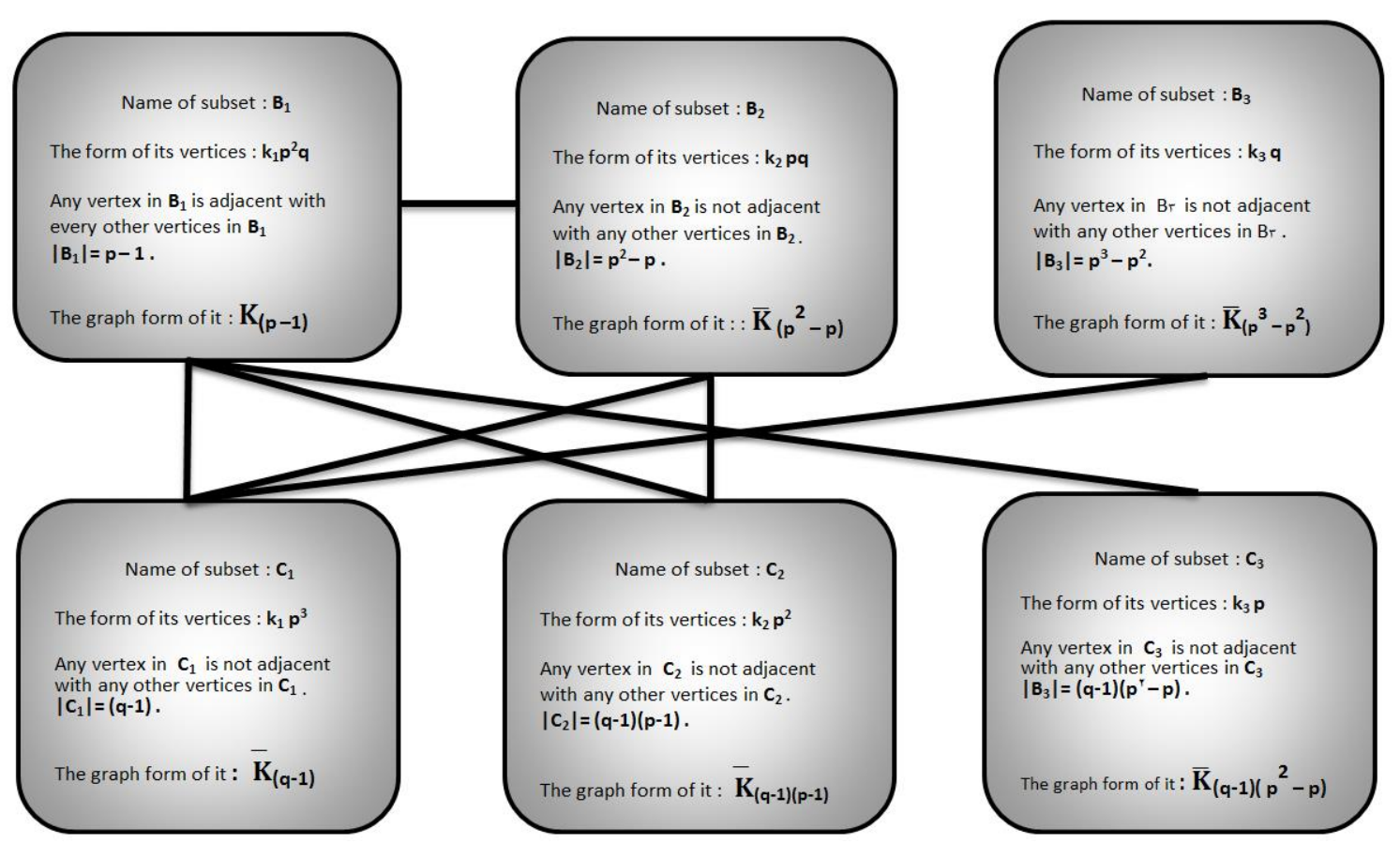




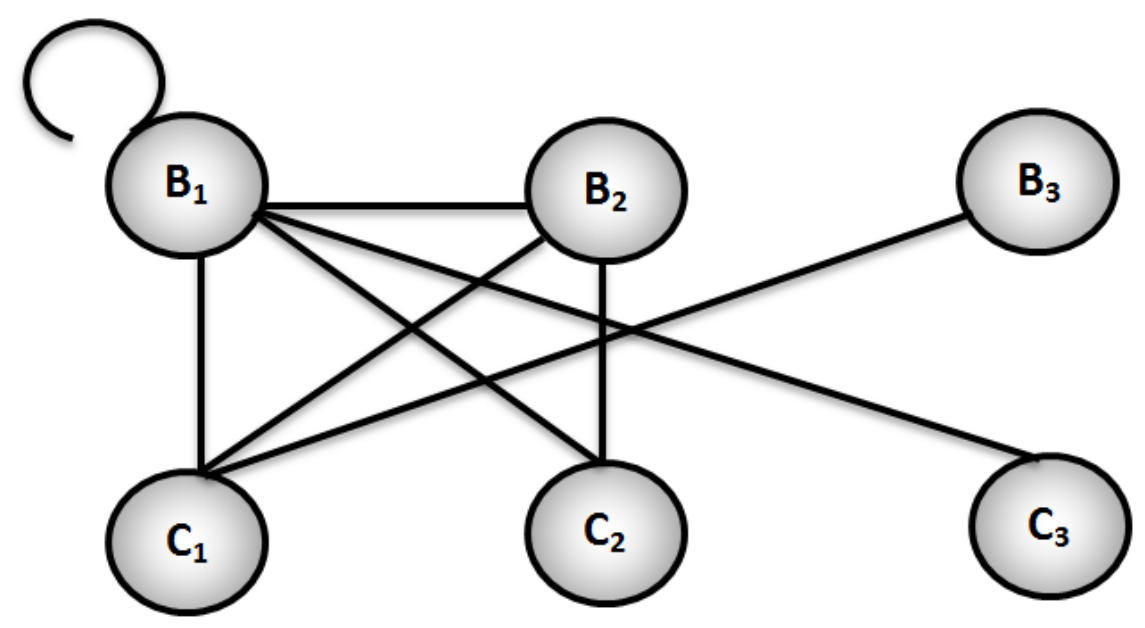

Figure 3.1 : The general form of the graph $\Gamma\left(Z_{p^{3} q}\right)$

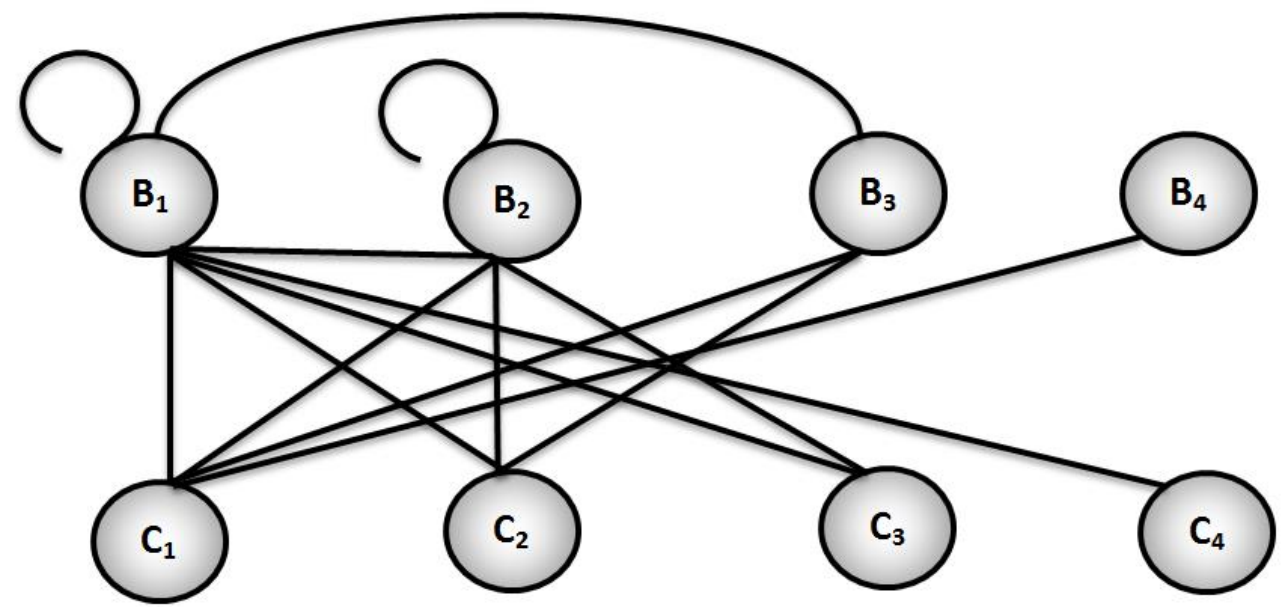

Figure 3.2 : The general form of the graph $\Gamma\left(\mathrm{Z}_{\mathbf{p}^{4} \mathbf{q}}\right)$

We can now give the general form of the graph $\Gamma\left(\mathrm{Z}_{\mathrm{p}^{\mathrm{m}}}\right)$, as the following : 


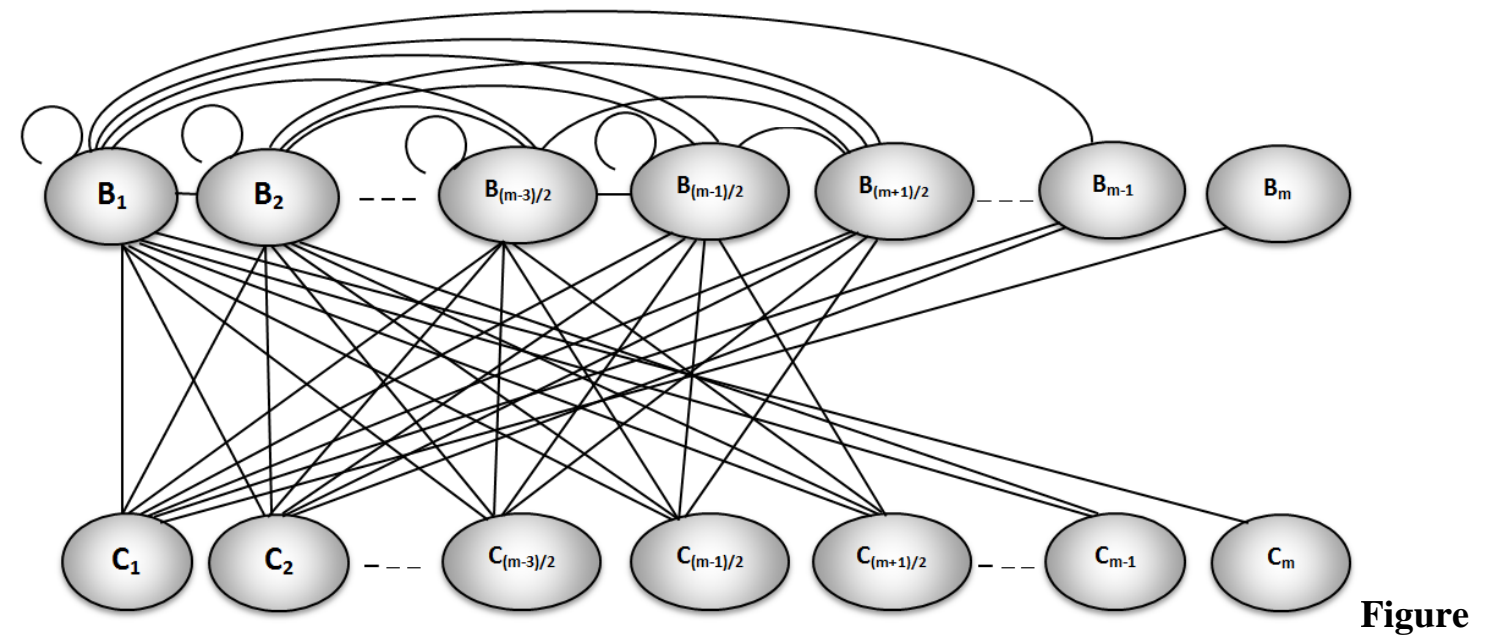

3.3 : The general form of the graph $\Gamma\left(Z_{p^{m}} q\right)$, where $m$ is an odd number with $m \geq 5$.

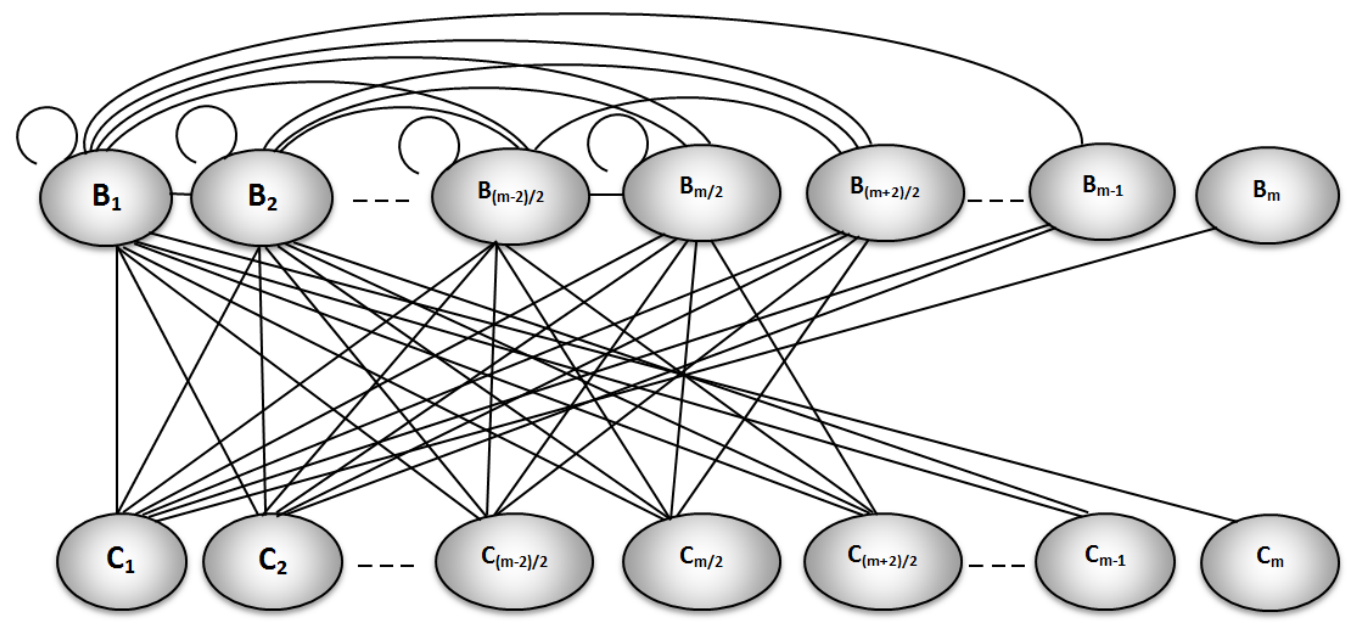

Figure 3.4 : The general form of the graph $\Gamma\left(Z_{p^{m}}\right)$, where $m$ is an even number with $m \geq 6$.

Lemma 3.5 $\left[8\right.$, Proposition 3.2.] : Let $\mathrm{Z}_{\mathrm{p}^{\mathrm{m}} \mathrm{q}}$ be a ring of integers modulo $\mathrm{p}^{\mathrm{m}} \mathrm{q}$. Then, $\operatorname{diam}\left(\Gamma\left(\mathrm{Z}_{\mathrm{p}^{\mathrm{q}}}\right)\right)=3$.

Now, we give the main result in this section.

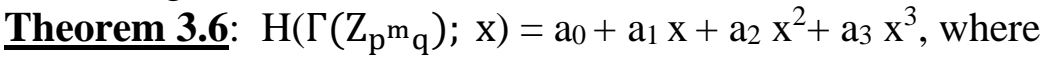
$\mathrm{a}_{0}=(\mathrm{p}+\mathrm{q}-1) \mathrm{p}^{\mathrm{m}-1}-1$,

$\mathrm{a}_{1}=\frac{1}{2}[2 \mathrm{mq}(\mathrm{p}-1)-(\mathrm{m}+1) \mathrm{p}+\mathrm{m}] \mathrm{p}^{\mathrm{m}-1}-\frac{1}{2} \mathrm{p}^{\left\lfloor\frac{\mathrm{m}}{2}\right\rfloor}+1$,

$\mathrm{a}_{2}=\frac{1}{2}\left(\mathrm{p}^{2}+\mathrm{q}^{2}-1\right) \mathrm{p}^{2 \mathrm{~m}-2}+\frac{1}{2}[(\mathrm{~m}-4) \mathrm{p}-2(\mathrm{~m}-1) \mathrm{pq}+(2 \mathrm{~m}-5) \mathrm{q}-\mathrm{m}+5] \mathrm{p}^{\mathrm{m}-1}+\frac{1}{2} \mathrm{p}\left\lfloor\frac{\mathrm{m}}{2}\right\rfloor$, and $\mathrm{a}_{3}=(\mathrm{q}-1)(\mathrm{p}-1)\left(\mathrm{p}^{2 \mathrm{~m}-2}-\mathrm{p}^{\mathrm{m}-1}\right)$.

Proof : By Lemma 3.5 we have $\operatorname{diam}\left(\Gamma\left(\mathrm{Z}_{\mathrm{p}^{\mathrm{m}}}\right)\right)=3$, then $\mathrm{H}\left(\Gamma\left(\mathrm{Z}_{\mathrm{p}^{\mathrm{m}} \mathrm{q}}\right) ; \mathrm{x}\right)=\mathrm{a}_{0}+\mathrm{a}_{1} \mathrm{x}+\mathrm{a}_{2}$ $x^{2}+a_{3} x^{3}$, where $a_{i}=d\left(\Gamma\left(Z_{p^{m}}\right), i\right)$, for $i=0,1,2,3$.

To find a 0 , by Lemma 3.3 we have $\mathrm{a}_{0}=\mathrm{d}\left(\Gamma\left(\mathrm{Z}_{\mathrm{p}^{\mathrm{m}_{\mathrm{q}}}}\right), 0\right)=\left|\mathrm{Z}^{*}\left(\mathrm{Z}_{\mathrm{p}^{\mathrm{m}} \mathrm{q}}\right)\right|=(\mathrm{p}+\mathrm{q}-1) \mathrm{p}^{\mathrm{m}-1}-1$.

Now, to find $\mathrm{a}_{1}$, let $\mathrm{x}, \mathrm{y} \in \mathrm{Z}^{*}\left(\mathrm{Z}_{\mathrm{p}^{\mathrm{m}} \mathrm{q}}\right)$ such that $\mathrm{d}(\mathrm{x}, \mathrm{y})=1$ (i.e. $\mathrm{xy}=0$ ), hence by using Theorem 3.4 there are two cases : 
Case 1: $x \in B_{i}$ and $y \in B_{j}$ with $i+j \leq m$, for some $1 \leq i, j \leq m$, the same as the proof of Theorem 2.7, we get that there are $\mathrm{m}_{1}$ edges in this case, where $\mathrm{m}_{1}=\frac{1}{2}\left[(\mathrm{~m}-1) \mathrm{p}^{\mathrm{m}}-\mathrm{m} \mathrm{p}^{\mathrm{m}-1}-\mathrm{p}^{\left\lfloor\frac{\mathrm{m}}{2}\right\rfloor}+2\right] \ldots(*)$

Case $2: x \in B_{i}$ and $y \in C_{j}$ with $i+j \leq m+1$, for some $1 \leq i, j \leq m$, this holds if and only if $1 \leq \mathrm{i} \leq \mathrm{m}$ and $1 \leq \mathrm{j} \leq \mathrm{m}-\mathrm{i}+1$, because that $\mathrm{i}+\mathrm{j} \leq \mathrm{m}+1$ for any $1 \leq \mathrm{i} \leq \mathrm{m}$ and $1 \leq$ $\mathrm{j} \leq \mathrm{m}-\mathrm{i}+1$, so that $\mathrm{i}+\mathrm{j}>\mathrm{m}+1$ in otherwise of this case, so that there are $\mathrm{m}_{2}$ edges, where $\mathrm{m}_{2}=\sum_{\mathrm{i}=1}^{\mathrm{m}}\left(\left|\mathrm{B}_{\mathrm{i}}\right| \sum_{\mathrm{j}=1}^{\mathrm{m}-\mathrm{i}+1}\left|\mathrm{C}_{\mathrm{j}}\right|\right)$, and since $\left|\mathrm{B}_{\mathrm{i}}\right|=\left(\mathrm{p}^{\mathrm{i}}-\mathrm{p}^{\mathrm{i}-1}\right)$ for $1 \leq \mathrm{i} \leq \mathrm{m}$, then by Lemma 3.3, we get that

$$
\begin{aligned}
\mathrm{m}_{2}=\sum_{\mathrm{i}=1}^{\mathrm{m}}\left(\mathrm{p}^{\mathrm{i}}-\mathrm{p}^{\mathrm{i}-1}\right) \mathrm{p}^{\mathrm{m}-\mathrm{i}+1-1}(\mathrm{q}-1) & =\sum_{\mathrm{i}=1}^{\mathrm{m}} \mathrm{p}^{\mathrm{i}-1}(\mathrm{p}-1) \mathrm{p}^{\mathrm{m}-\mathrm{i}}(\mathrm{q}-1) \\
\cdot=\sum_{\mathrm{i}=1}^{\mathrm{m}}(\mathrm{p}-1)(\mathrm{q}-1) \mathrm{p}^{\mathrm{m}-1} & =\mathrm{m}(\mathrm{p}-1)(\mathrm{q}-1) \mathrm{p}^{\mathrm{m}-1} \ldots(* *)
\end{aligned}
$$

Now, from $(*)$ and $(* *)$, we get that

$$
\begin{aligned}
\mathrm{a}_{1} & =\mathrm{m}_{1}+\mathrm{m}_{2}=\frac{1}{2}(\mathrm{~m}-1) \mathrm{p}^{\mathrm{m}}-\frac{1}{2} \mathrm{~m} \mathrm{p}^{\mathrm{m}-1}-\frac{1}{2} \mathrm{p}^{\left\lfloor\frac{\mathrm{m}}{2}\right\rfloor}+1+\mathrm{m}\left(\mathrm{p}^{\mathrm{m}}-\mathrm{p}^{\mathrm{m}-1}\right)(\mathrm{q}-1) \\
& =\frac{1}{2} \mathrm{~m} \mathrm{p}^{\mathrm{m}}-\frac{1}{2} \mathrm{p}^{\mathrm{m}}-\frac{1}{2} \mathrm{~m} \mathrm{p}^{\mathrm{m}-1}-\frac{1}{2} \mathrm{p}^{\left\lfloor\frac{\mathrm{m}}{2}\right\rfloor}+1+\mathrm{m} \mathrm{p}^{\mathrm{m}} \mathrm{q}-\mathrm{mp}^{\mathrm{m}}-\mathrm{m} \mathrm{p}^{\mathrm{m}-1} \mathrm{q}+\mathrm{mp}^{\mathrm{m}-1} \\
& =\frac{1}{2}[2 \mathrm{mq}(\mathrm{p}-1)-(\mathrm{m}+1) \mathrm{p}+\mathrm{m}] \mathrm{p}^{\mathrm{m}-1}-\frac{1}{2} \mathrm{p}^{\left\lfloor\frac{\mathrm{m}}{2}\right\rfloor}+1
\end{aligned}
$$

Now, to find $a_{i}$, for $i=2,3$,in the first, we shall find $a_{3}$.

Let $x, y \in Z^{*}\left(Z_{p^{m}}\right)$ such that $d(x, y)=3$, then $x \in B_{i}$ and $y \in C_{j}$ for some $1 \leq i, j \leq m$, in this case, we see that $d(x, y)=3$ if and only if $i=m$ and $2 \leq j \leq m$, because that $d(x, y) \leq$ 2 for any $1 \leq \mathrm{i} \leq \mathrm{m}-1$ and $2 \leq \mathrm{j} \leq \mathrm{m}$, also that $\mathrm{d}(\mathrm{x}, \mathrm{y})=1$ for $1 \leq \mathrm{i} \leq \mathrm{m}$ and $\mathrm{j}=1$, therefore the number of pairs of vertices that are distance three apart is $\left(\left|B_{m}\right| \sum_{j=2}^{m}\left|C_{j}\right|\right)$, i.e. $a_{3}=\left|B_{m}\right| \sum_{j=2}^{m}\left|C_{j}\right|$, since $\left|B_{m}\right|=\left(p^{m}-p^{m-1}\right)$, then by Lemma 3.3, we get that : $\mathrm{a}_{3}=\left(\mathrm{p}^{\mathrm{m}}-\mathrm{p}^{\mathrm{m}-1}\right)(\mathrm{q}-1)\left(\mathrm{p}^{\mathrm{m}-1}-1\right)=(\mathrm{q}-1)(\mathrm{p}-1)\left(\mathrm{p}^{2 \mathrm{~m}-2}-\mathrm{p}^{\mathrm{m}-1}\right)$.

Now, to find a $a_{2}$ we shall use lemma 2.9 , that is :

$$
\begin{aligned}
\mathrm{a}_{2} & =\frac{1}{2} \mathrm{a}_{0}\left(\mathrm{a}_{0}+1\right)-\mathrm{a}_{0}-\mathrm{a}_{1}-\mathrm{a}_{3}=\frac{1}{2} \mathrm{a}_{0}\left(\mathrm{a}_{0}-1\right)-\mathrm{a}_{1}-\mathrm{a}_{3} \\
& =\frac{1}{2}\left((\mathrm{p}+\mathrm{q}-1) \mathrm{p}^{\mathrm{m}-1}-1\right)\left((\mathrm{p}+\mathrm{q}-1) \mathrm{p}^{\mathrm{m}-1}-2\right)-\left[\frac{1}{2}(2 \mathrm{mq}(\mathrm{p}-1)-(\mathrm{m}+1) \mathrm{p}+\mathrm{m}) \mathrm{p}^{\mathrm{m}-1}\right. \\
- & \left.\frac{1}{2} \mathrm{p}^{\left\lfloor\frac{\mathrm{m}}{2}\right\rfloor}+1\right]-(\mathrm{q}-1)(\mathrm{p}-1)\left(\mathrm{p}^{2 \mathrm{~m}-2}-\mathrm{p}^{\mathrm{m}-1}\right) \\
& =\frac{1}{2}\left(\mathrm{p}^{2}+\mathrm{q}^{2}-1\right) \mathrm{p}^{2 \mathrm{~m}-2}+\frac{1}{2}[(\mathrm{~m}-4) \mathrm{p}-2(\mathrm{~m}-1) \mathrm{pq}+(2 \mathrm{~m}-5) \mathrm{q}-\mathrm{m}+5] \mathrm{p}^{\mathrm{m}-1}+\frac{1}{2} \mathrm{p}^{\left\lfloor\frac{\mathrm{m}}{2}\right\rfloor} .
\end{aligned}
$$

Corollary 3.7 : $\mathrm{W}\left(\Gamma\left(\mathrm{Z}_{\mathrm{p}^{m_{\mathrm{q}}}}\right)\right)=\left[\mathrm{p}^{2}+\mathrm{q}^{2}+3(\mathrm{pq}-\mathrm{p}-\mathrm{q})+2\right] \mathrm{p}^{2 \mathrm{~m}-2}+\frac{1}{2}[(\mathrm{~m}-3) \mathrm{p}-$ $2(\mathrm{~m}+1) \mathrm{pq}+2(\mathrm{~m}-2) \mathrm{q}] \mathrm{p}^{\mathrm{m}-1}+\frac{1}{2} \mathrm{p}^{\left\lfloor\frac{\mathrm{m}}{2}\right\rfloor}+1$.

\section{REFERENCES}

[1] Ahmdi M. R. and Nezhad R.J., (2011), "Energy and Wiener Index of Zero-Divisor Graphs", Iranian Journal of Mathematical Chemistry, Vol. 2, No. 1, 45-51.

[2] Anderson D. and Livingston P., (1999), "The Zero-Divisor Graph of a Commutative Ring", J. Algebra, 217, 434-447.

[3] Anderson D. and Naseer M., (1993), "Beck's Coloring of a Commutative Ring", J. Algebra 159 500-514.

[4] Axtell M., Stickles J., and Trampbachls W., (2009), "Zero-Divisor Ideals and Realizable Zero-Divisor Graph", Involve a journal of mathematics Vol. 2, No. 2 , $17-27$.

[5] Beck I., (1988), "Coloring of Commutative Rings", J. Algebra 116 208-226. 
[6] Chartrand G., and Lesniak L., (1986), "Graphs and Digraphs", $3^{\text {rd }}$ ed.,Wadsworth and Brooks / Cole, California.

[7] Hosoya H., (1985), "On Some Counting Polynomials in Chemistry", Discrete Applied Math. Vol.19, 239-257.

[8] Shukar N.H., Mohammad H.Q. and Ali A.M., (2012), "The Zero-Divisor Graph of $\mathrm{Z}_{\mathrm{p}} \mathrm{n}_{\mathrm{q}}$ ", Int. Journal of Algebra, Vol. 6, No. 22, 1049-1055.

[9] Wiener H., (1947), "Structural Determination of The Paraffin Boiling Points", J. Am. Chem. Soc. 6917-20. 